\title{
The Generation of Management Innovation in Microentreprises: Absorptive Capacity and Entrepreneur-CPA's relationship
}

\author{
Agnès MAZARS-CHAPELON \\ Université de Montpellier, MRM - Labex Entreprendre \\ IUT de Montpellier- Département Informatique \\ 99 av. d'Occitanie, 34296 Montpellier Cedex 5, France \\ E-mail: agnes.mazars-chapelon@umontpellier.fr
}

\section{Philippe CHAPELLIER}

Université de Montpellier, MRM - Labex Entreprendre

Polytech Montpellier - Département IG

CC 419 - Place Eugène Bataillon, 34095 Montpellier, France

E-mail: philippe.chapellier@umontpellier.fr

\section{Sophie MIGNON}

Université de Montpellier, MRM - Labex Entreprendre

IUT de Nîmes- Département GEA

8 rue Jules Raimu, 30907 Nîmes Cedex 02, France

E-mail: sophie.mignon@umontpellier.fr

\begin{abstract}
In microentreprises, considering the management knowledge basis of the entrepreneur, the generation of management innovation (MI) is a crucial question. In this qualitative case study of a microentreprise, we follow Mol and Birkinshaw (2014) who claimed for research on management innovation generation, highlighting "how relations with external and internal partners can deliver knowledge" (2009). We focus on the entrepreneurCPA relationship to study how the relationship between the CPA as an external change actor and the entrepreneur as an internal change actor can be a lever of MI generation in microentreprises. More particularly, we aim at understanding how the external CPA's knowledge can be internalized by the entrepreneur in microentreprises through the acquisition, assimilation, transformation and exploitation of knowledge. And more particularly, we propose to highlight the key drivers of the generation of management innovation in microentreprises through the study of the process by which a potential ACAP becomes realized (Cohen and Levinthal, 1990; Lane et al., 2006; Gebauer et al., 2012; Marabelli and Newell, 2014).
\end{abstract}


Keywords: Management innovation, Absorptive capacity, Microentreprise, Relationship, CPA, Entrepreneur

\section{Biographical notes:}

Agnès Mazars-Chapelon is an Associate Professor at the University of Montpellier. She graduated from ESSEC in 1995. She conducts management research about instrumental organizational dynamics in Montpellier Research Management (MRM). She is particularly interested in studying interactions between management tools, innovation and cognitive and emotional processes in organizational and management control.

Philippe Chapellier is a Professor of management at the University of Montpellier. He is a member of Innovation and management laboratories such as MRM (Montpellier Research Management) and Labex Entreprendre. He is currently working on innovative management devices and knowledge transfer in SME. His research interests cover innovation, management control and SME.

Sophie Mignon is a Professor at the University of Montpellier and a former student of the ENS Cachan. Her research topics are organizational sustainability, knowledge management, in particularly factors facilitating knowledge sharing and organizational learning but also exploration processes as sources of innovation. She is responsible for the 'innovation' axis in Montpellier Research Management (MRM) and Co-Director of the research network on innovation (RRI). 


\section{Introduction}

Management innovation is essential for long term competitive advantage (Hamel, 2006), and management innovation (MI) has recently been particularly highlighted by researchers (Damanpour, 1987, 1991; Damanpour and Evan, 1984; Damanpour et al., 1989; Mol and Birkinshaw, 2009). Regarding SMEs which represent 99\% of European firms (European Commission, 2003), management innovation can play a key role, especially for microentreprises which are an important source of technological, product or process innovation. But whereas management innovation appears to be crucial for organizations which are important regarding innovative and strategic issues as microentreprises are, little is known about how management innovation emerges, especially within microentreprises.

Recently, Volberda and colleagues (2014, p. 1245) and Mol and Birkinshaw (2014) claimed for research on management innovation generation: "there is relatively little research on the 'genesis' of management innovation, that is, how specific innovations first emerged" (Mol and Birkinshaw, 2014, p. 1288). In this paper, we contribute to Management Innovation literature, and more specifically on Management Innovation generation in microentreprises.

Microentreprises are particularly interesting to study MI generation because the average internal knowledge basis is less important in SMEs than in bigger organizations (Gray, 2006). This is especially true for management knowledge since entrepreneurs often know little about management (Freel, 1999, 2005), whereas they rely on CPAs as an external knowledge source.

Following Volberda et al. (2014) who claimed for research on micro-foundations of MI and contextual variation of MI (p.1259-1260), we aim at understanding how microentreprises introduce new ways of managing, which means management innovation. As recommended by Volberda et al. (2014), our objective in this paper is "to gain further understanding of the interrelationship between these change agents" (p. 1259). And, focusing on the entrepreneurCPA relationship, this study follows that of Mol and Birkinshaw (2009) who highlighted "how relations with external and internal partners can deliver knowledge that helps firms implement a wide range of management practices, which then may or may not improve the firm's performance." (p.1269).

In this research, we aim at understanding how the relationship between the CPA as an external change actor and the entrepreneur as an internal change actor can be a lever of MI generation in microentreprises. We propose in this paper to study this process through the absorptive capacity lens (Cohen and Levinthal, 1990; Lane et al., 2006; Gebauer et al., 2012; 
Marabelli and Newell, 2014). As innovation, management innovation (Mol and Birkinshaw, 2009) can be considered as a combination of knowledge, and "the introduction of management practices that are new to the firm » (Mol and Birkinshaw, 2009). In this paper, we rely on this approach of management innovation.

The paper is structured as follows. First, we present the theoretical background of the research. Second, we describe the qualitative case study we conducted around three relationships between an entrepreneur of a young consulting company operating in the health field and her three different CPAs. Finally, we develop and discuss in Section 4 the main findings of this research.

\section{Theoretical background: Management Innovation Generation, Change Actors and Absorptive Capacity}

First, we present management innovation generation and the role of change actors in MI process. Second, in order to understand how the relationship between the CPA as an external change actor and the entrepreneur as an internal change actor can be a lever of MI generation in microentreprises, we propose to focus on the micro foundations of the MI process that is management innovating, through the absorptive capacity concept.

\subsection{Management innovation generation, knowledge and change actors}

Several definitions have been proposed for management innovation. It is «the invention and implementation of a management practice, process, structure, or technique that is new to the state of the art and is intended to further organizational goals » (Birkinshaw et al., 2008, p. 825). It also can be defined as " the introduction of management practices that are new to the firm and intended to enhance firm performance » (Mol and Birkinshaw, 2009). According to Volberda et al. (2014), these different approaches are not isolated from one another since they study management innovation through "one of the three stages of the process of management innovation, namely generation, diffusion, and adoption" (Volberda et al., 2014, p. 1250). Thus, Volberda and his colleagues identify three types of MI: «new to the world (type 1), new to the organization and adapted to the setting (type 2), and new to the organization without adaptation (type 3)»(Volberda et al., 2014, p.1250). These three types of MI can be related to the radical innovations (type 1) or incremental innovations (type 2 and 3). And differences between radical and incremental innovations can be associated to the newness of the developed and implemented ideas. 
Indeed, according to Van de Ven (1986), innovation can be considered as the development and the implementation of new ideas (Van de Ven, 1986). And new ideas emerge through new combinations of knowledge. For instance, many researchers show that technological innovation emerges when organizations get new knowledge which is recombined with a technical existing knowledge (Fey and Birkinshaw, 2005; Katila and Ahuja, 2002; Laursen and Salter, 2006; Rosenkopf and Nerkar, 2001).

In the same way, Mol and his colleagues (2009) propose to consider management innovation as the combination of knowledge, particularly through relationships between external and internal partners. Managers are looking for new ideas they combine with existing knowledge and conditions in their organization. This leads to the introduction of new practices, i.e. the introduction of a managerial innovation within the meaning of Damanpour (1987). Thus, a crucial question is primarily that of the access to these sources of new knowledge. It appears that these sources are often external.

More precisely, Mol and his colleagues (2009) study the process by which the relationship between internal and external partners can lead to an exchange of knowledge, which possibly causes new management practices. Through an inter-organizational analysis, they highlight the relationships between internal and external partners. They show that, although the contextual elements are important, the combination of external elements with internal contextual factors is essential for the emergence of management innovation. More recently, Mol and Birkinshaw (2014) studied the form of external involvement on the management innovation process: their objective was to "to understand the different forms of external involvement that potentially shape the management innovation process, and how these different forms influence the type of innovation that emerges." (p.1289). They showed that the type 2 and 3 MI (incremental innovations) are associated with the presence of external change agents, whereas "the absence of external experience is associated with systemic and radical innovations" (Mol and Birkinshaw, 2014, p.1305).

In this research, we aim at understanding how management innovation is generated in microentreprise through the relationship between external and internal change actors. It consists in questioning how internal knowledge can be recombined with external knowledge since it is essential to understand how management innovation is generated.

\subsection{Management Innovating and Absorptive Capacity}

According to Volberda et al. (2014), understanding how management innovation is generated consists in understanding "how a management practice is brought into being in a particular 
organization” (p.1250). And more specifically, Mol and Birkinshaw (2014) propose to study 'the 'genesis' of management innovation, that is, how specific innovations first emerged, through a process [they] will call management innovating... [which] involves creation” (Mol and Birkinshaw, 2014, p. 1288). Thus, questioning how the relationship between the CPA as an external change actor and the entrepreneur as an internal change actor can be a lever of MI generation in microentreprises leads to questioning the internalization process of the CPA's external knowledge by the entrepreneur in microentreprises. Indeed, it is necessary to study through internal and external change actors' relationships the micro foundations of management innovation as «pockets of knowledge [which] are interrelated » (Volberda et al., 2014, p.1251). To do so, we can study the knowledge conversion process.

Following Nonaka (1994) and Nonaka and Takeuchi (1997), the knowledge conversion process can be highlighted by the distinction between tacit and explicit knowledge. Explicit knowledge is easily expressed, captured and re-used, whereas tacit knowledge "is deeply rooted in action and in an individual's commitment to a specific context" (Nonaka, 1991: 98). Explicit and tacit knowledge interacts through the conversion process which consists of four stages: socialization, externalization, combination and internalization.

How knowledge can be externalized has been largely studied (Hendricks, 1999). Davenport and Prusack (1998) highlight how knowledge is transferred between the ones who know and the others who don't. At this stage, sharing a common language is essential (Nahapiet and Ghoshal, 1998; Boland and Tenkasi, 1995; Marti, 2005). In microentreprises, the entrepreneur often knows little about accounting and financial issues, whereas the CPA is an expert about these questions. Moreover, the entrepreneur and the CPA rarely share a common language. Therefore, the CPA must be able to translate what he knows into the entrepreneur's words. In other words, the question here consists in connecting the 'world' of the distant actors (Avenier and Schmitt, 2005). The externalization stage between the external CPA and internal entrepreneur of the microentreprise can be considered as a translation process. It depends on the CPA's ability to be close to the entrepreneur.

Then, the CPA's externalized and explicit knowledge has to be adapted in order to support the entrepreneur's action. This is the internalization stage (Nonaka, 1994; Hendriks, 1999), also called absorptive stage (Davenport and Prusack, 1998). Internalizing knowledge is a cognitive process in two steps. The first step consists in de-contextualizing knowledge so as the individual perceives knowledge; the second step consists in re-contextualizing knowledge. 
The recontextualization issue appears to be fundamental since at this stage of the knowledge construction process, the entrepreneur gives sense to the perceived external knowledge. Recontextualizing external knowledge can be analyzed as transferring knowledge in one's own culture (Brannen, 2004), through first a reformulation stage and then an absorption stage (Hull, 1998; Gavigan, Ottitsch and Mahroum, 1999; Thompson, Warhurst and Callaghan, 2001).

In order to understand how the CPA's external knowledge is internalized by the microenterprise entrepreneur and therefore how the relationship between external and internal change actors can be a lever of management innovation in microentreprises, we follow many scholars who rely on the absorptive capacity concept (ACAP) to study innovation and materiality (Gebauer et al., 2012; Marabelli and Newell, 2014) and knowledge conversion in SME (Gray, 2006; Flatten et al., 2011), since "ACAP uses external knowledge to foster internal innovation" (Flatten et al., 2011, p.138).

Absorptive capacity refers to the firm's ability to identify, assimilate and exploit knowledge from the environment. At first, Cohen and Levinthal (1990) defined the absorptive capacity as an organizational feature which depends on organizational resources, existing tacit and explicit organizational knowledge, internal routines, managerial competencies and organizational culture. Since it was first developed by Cohen and Levinthal (1990), this concept has been largely studied by organizational researchers (Lane et al., 2006). In this research we refer to the concept of absorptive capacity in a processual approach, following Zahra and George (2002).

These researchers identify four steps in the process of absorption of knowledge, namely the acquisition, the assimilation, the transformation and finally the exploitation of knowledge. At an organizational level, this analytic framework is interesting for it takes into account tacitexplicit and internal-external knowledge, and the conversion knowledge process by Nonaka and Takeuchi. Moreover, it relies on decontextualization - recontextualization process which is associated to the absorptive process (Brannen, 2004; Hull, 1998; Gavigan, Ottitsch and Mahroum, 1999; Thompson, Warhurst and Callaghan, 2001).

More precisely, Zahra and George (2002) propose to qualify the absorptive capacity (ACAP) as either potential or realized, considering the different steps of the absorptive process. The potential capacity corresponds to the external knowledge that the organization could acquire and use, and the realized ACAP is carried out with the external knowledge that the 
organization effectively acquired and used (Zahra and Georges, 2002, p. 186). And our research objective consists in understanding how the entrepreneur in a microentreprise internalizes CPA's external knowledge. Actually, we aim at understanding how the entrepreneur's potential ACAP becomes a realized ACAP.

Several factors have been identified to understand how the potential ACAP can become a realized ACAP. Researchers stress cognitive factors and the similarity of the internal and external knowledge basis, but also relational factors (Lane et al., 2006; Jansen et al., 2006). Dyer and Singh (1998) highlight the importance of interactions and relationships developed between the organization and its external partners, at an organizational and individual level. Moreover, Lane and Lubatkin (1998) showed that the specificity of organizational actors involved in the inter-organizational relationship should be taken into account. Imbert and Chauvet (2012) studied the mechanisms of absorptive capacity in the case of a suppliercustomer relationship. They showed that the potential ACAP became realized when the external supplier and internal customer knowledge basis were similar, when organizational routines and coordination occurred, and when the involved partners such as the external supplier were motivated.

In their study, Imbert and Chauvet (2012) focused on the external source of knowledge, and not on the internal customer. On the contrary, in this study, we aim at studying the relationship between the CPA and the entrepreneur and its consequences on the absorptive capacity of the internal actor, i.e. the entrepreneur. Moreover, we are interesting in studying the relationship between the CPA and the entrepreneur of microentreprise, whereas their knowledge bases are often little similar: for the entrepreneur, rather qualitative, for the CPA, rather formal and quantitative (Bescos and Mendoza, 1998; Beldi and Cheffi, 2005; Mintzberg, 2006; Vallerand, Berthelot and Morrill, 2008).

To sum up, when we aim at understanding how the relationship between the CPA as an external change actor and the entrepreneur as an internal change actor can be a lever of MI generation in microentreprises, we aim at understanding how the external CPA's knowledge can be internalized by the entrepreneur in microentreprises through the acquisition, assimilation, transformation and exploitation of knowledge. And more particularly, we propose to highlight the key drivers of the generation of management innovation in microentreprises through the study of the process by which a potential ACAP becomes realized. 


\section{Empirical Setting}

In this section we present our research design. We conducted an in-depth case study of a young consulting company in organization and strategy in the health sector. In a seek for anonymity, the name of the company has been changed for $\mathrm{H} 3 \mathrm{C}$ (Health Care Consulting Company). The entrepreneur collaborated with three different CPAs since $\mathrm{H} 3 \mathrm{C}$ was created in 2011. Thus, the $\mathrm{H} 3 \mathrm{C}$ case is particularly interesting to understand how the relationship between the CPA as an external change actor and the entrepreneur as an internal change actor can be a lever of MI generation in microentreprises. More particularly, we propose to highlight the key drivers of the generation of management innovation in microentreprises through the study of the process by which a potential ACAP becomes realized.

\subsection{Research design}

We conducted an in-depth case study of a consulting company in organization and strategy in the health sector, the Health Care Consulting Company (H3C), which was created in 2011. This case was selected following Yin's recommendations (2003). Since we aimed at highlighting the micro-processes and drivers associated with the absorptive capacity, we chose to focus on a young microentreprise, its entrepreneur and her relationship with an external CPA.

Consequently, we controlled the cognitive and relational factors which may influence the absorptive capacity (Jansen et al., 2006; Lane et al., 2006).

On the one hand, even if entrepreneurs in microentreprises generally know less than a CPA about accounting and finance, the internal and external knowledge basis are not so distant in the studied case. Indeed, the entrepreneur Mrs. I., and her partner Mr. J., are former consultants in the health sector. But unlike many consultants in the health sector, they are neither medical practitioners nor scientists, but managers. The entrepreneur Mrs. I. is graduated from a famous top French business school. Our study is particularly focused on Mrs. I. since she carried out the business project and was in charge of the accounting and financial issues. As a former branch manager and consultant, not only is Mrs. I. familiar with strategic issues and management accounting problems, but she is also able to acquire and use the accounting and financial knowledge of a CPA. Consequently, in the $\mathrm{H} 3 \mathrm{C}$ case, we can emphasize a potential absorptive capacity, namely an external knowledge that the entrepreneur can identify, acquire and use. Now the question is to know if the potential ACAP becomes realized in $\mathrm{H} 3 \mathrm{C}$. And how does this happen ? 
On the other hand, we adopt in this research a relational approach of the absorptive capacity (Jansen et al., 2006). Studying the H3C case is particularly interesting from this point of view, because it allows us to focus on three different relationships between the entrepreneur and her various CPAs. Indeed, since H3C was created in 2011, the entrepreneur collaborated with three different CPAs. Two of them were official, the third one was a kind of shadow manager. We will further present more in detail the history of these relationships. The three different relationships between the entrepreneur and her CPAs help us conducting a cross analysis of the collected data.

Lastly, we seek to identify the emergence of organizational routines around management tools which could clarify the knowledge internalization process through potential and realized ACAP, and thus the generation of management innovation. In $\mathrm{H} 3 \mathrm{C}$, which is a young microentreprise, organizational routines are not installed yet.

We collected data through semi directed interviews with the entrepreneur and the CPA. On the whole, nearly 10 hours of interviews were led between May 2012 and September 2013. We also studied management tools used by the entrepreneur and we asked her to explain them. All the interviews were recorded and transcribed. We relied on Miles and Huberman' recommendations (2003) about qualitative analysis to analyze the data. We coded interviews around two dimensions: the relationship between the entrepreneur and the CPAs, and the different management tools used by the entrepreneur in this relationship. This allowed us to build first three analytic tables. The first table analyzed the different stages of the relational process between the entrepreneur and the CPAs; the second one was about the different management tools, and the third one about knowledge. These three tables enabled us to clarify the process of internalization of knowledge for each CPA-Entrepreneur relationship, through the dynamics of the mobilized management tools. More precisely, we highlighted in the three studied relationships the four stages of absorptive process, - namely acquisition, assimilation, transformation and exploitation - , but also the characteristics of the relationship and the management tools mobilized in this process.

\subsection{The H3C case: from a relational story to a realized absorptive capacity}

The $\mathrm{H} 3 \mathrm{C}$ case help us to highlight the key drivers of the generation of a management innovation through the study of the process by which a potential ACAP becomes realized. First, we study this case through the relational story of the entrepreneur with her three different CPAs. The first CPA, we call CPA1, is an auditor who has been recommended by a 
business partner. But after a few months, the entrepreneur decides to stop the relationship with CPA1 and chooses another CPA, we will call CPA2. And, from the beginning, Mrs. I. regularly consults a third CPA to which she is very close: Mr. Y. We call him CPA 3. First, we can analyze the relationships between the entrepreneur and the three CPAs.

The entrepreneur chose CPA1 following the recommendations of her business network professional. She was very interested in getting advice about her business project. CPA1 was selected because he was the manager of a small organization, and not from a Big Four. But CPA1 appears to delegate at the last moment some important issues to unexperienced employees. Information between CPA1 and the entrepreneur do not even forward. And a major incident occurs about information transfer. Following this incident, a crisis meeting is arranged with CPA1 at the request of the entrepreneur. In order to prepare this meeting, Mrs. I. prepares questions, considering CPA3 remarks. But, CPA1 adopts a very formal and critical approach. The distrust settles. Then the entrepreneur decides to mandate another CPA: CPA2 from one of the Big Four. This choice is opposite to the initial idea of the entrepreneur about her potential business partners. However, CPA2 has been recommended by a former client of Mrs. I. who is both seduced by the ability of CPA2 to understand the specificities of $\mathrm{H} 3 \mathrm{C}$, and the opportunity to get fast and personalized advices through a hot line.

Parallel to these two relationships between the entrepreneur and her two official CPAs, a third relationship also exists with CPA3 who is purely consulted in a semi-official way. CPA3 is an experimented personal relation of the entrepreneur. However, Mrs. I. did not want to work with CPA3 in an official way. She was reluctant to mix private life and professional life. But she considered that this personal support given by CPA3 on her business problems was a kind of business opportunity. CPA3 appears as a "shadow cabinet". And beyond specific advices given by telephone or during informal personal meetings, -particularly at the time of the crisis situation with CPA1-, CPA3 offers to the entrepreneur simple management tools, such as commented Excel sheets which were e-mailed and explained by telephone. Moreover the simple information system framework proposed by CPA3 to the entrepreneur and used between Mrs. I. and CPA2 appears to be the basis for future specific management tools. Therefore we were able to characterize the absorptive capacity process in each studied relationship. We present them in table 1 above.

[Table 1] 
We analyze each relationship through the absorptive capacity lens. We identify four stages in the absorption process of the entrepreneur: acquisition, assimilation, the transformation and exploitation. Considering the different stages in the absorption process, the relationship between the entrepreneur and CPA3 is the more complete from the ACAP view. Not only CPA's knowledge appears to be acquired and assimilated but also transformed and exploited. On the other hand, the failure of the relationship with CPA1 breaks the absorption process at the acquisition stage. Lastly, the relationship with CPA2 appears at an intermediate stage. It exceeded the steps of acquisition and assimilation of the knowledge transmitted by CPA2. Nevertheless, if one considers this relationship without taking into account the interactions with CPA3, neither the transformation nor the exploitation stages are reached. The relationship with CPA3 helps the entrepreneur-CPA2 relationship be more complete. The potential ACAP is partially realized.

Finally, H3C case presents some «degrees » in the realized ACAP. We can identify the relational triggers in the absorptive process, particularly around the role of management tools in this relationship between the entrepreneur and the CPA. These results are presented and discussed below.

\section{Findings and Discussion}

We aimed at understanding how MI emerges in microentreprise, and more particularly how the relationship between the CPA as an external change actor and the entrepreneur as an internal change actor could be a lever of MI generation in microentreprises. The $\mathrm{H} 3 \mathrm{C}$ case study allows us to clarify the nature and the levers of management innovation process in microentreprises through the ACAP process. First, we show that MI in microentreprise is generated through an instrumental relationship between two major change actors: the entrepreneur as the internal change actor and the CPA as the external change actor. Secondly, we highlight the key drivers of the relationship between the entrepreneur and the CPA.

\subsection{The lever of MI generation in microentreprise: the instrumental relationship between external and internal change actors}

In this research, we show that in microentreprises such as $\mathrm{H} 3 \mathrm{C}$, management innovation is generated through the relationship between external and internal change actors who adapt and customize management tools. Doing so, they combine external CPA's and internal entrepreneur's knowledge. But among the three relationships between the entrepreneur and 
the three CPAs, it appears that it is the third relationship with the unofficial CPA, -called Shadow CPA for CPA3-, which is the more complete from the ACAP view. Indeed, this third relationship presents the ACAP four steps completed.

To begin, the first relationship between the entrepreneur and CPA1 is broken at the second step of the ACAP process, before external knowledge can be acquired. The ACAP process is stopped here.

Indeed, the entrepreneur is initially particularly concerned with cash management, which is a very common concern for microentreprise leaders. Two management tools are implemented very quickly by the entrepreneur: a reporting tool for project expenses and a cost accounting tool by project. The entrepreneur is completely familiar of this kind of tools, which are very common.

"I was used reporting expenses every month. Thus, we have already implemented analytics by project."

But, the entrepreneur is aware she needs an aggregated cash management tool, since she knows that managing a company is not the same thing than managing a series of projects. She calls upon CPA1, who doesn't help her, considering not to be specifically elected for that. Then two worlds clash: that of the entrepreneur eager to conduct action, and that of the CPA1, formal and rational.

"I tell him that I understand nothing in his logic there."

The entrepreneur is not confident that she is able to improve accounting and financial knowledge. She seeks advice from CPA3 in order to clarify information with CPA1.

"I had cheated a little. I had already prepared the questions with my partner and had already shown them to CPA3 to be sure that they were OK."

But finally the relationship with CPA1 fails, and the entrepreneur turns towards CPA2. Regarding this second relationship, we find that the ACAP process is in progress between the potential and realized ACAP. In this case, the same need for a cash management tool by the entrepreneur can be observed. CPA2 agrees to provide one, but only if the entrepreneur gives a general framework. And since the entrepreneur doesn't know anything about accounting issues, she seeks help from CPA3. 
"Shadow CPA gave us the general framework. And we showed it to CPA2."

Then knowledge from external CPA2 can be assimilated.

Finally we see that CPA3, who is the Shadow CPA, plays an important role in the absorptive capacity process. The ACAP process appears to be fully completed through the four stages in the third relationship between the entrepreneur and CPA3.

[Figure 1]

In the third relationship with Shadow CPA, not only CPA's external knowledge appears to be acquired and assimilated but also transformed and exploited by the entrepreneur.

The CPA3's support can also be observed in the exchanges of adequate tools which are translated into the entrepreneur's words. Besides, the entrepreneur finally adapts the CPA3 elements. She uses diagrams and visual frames to simplify. She also adapts the terms so as they be closer to her reality, and notes for her personal interest explanatory comments. For instance, the concept of running costs is associated with that of engaged expenditure, nearer to her concerns about cash management.

"I reappropriated the file given by CPA3 and put it in my words. I made a simplified diagram. I added comments: 'running costs' means 'what I incurred'."

The use of these tools by the entrepreneur is possible because they are adapted to the context of $\mathrm{H} 3 \mathrm{C}$. The entrepreneur re-contextualizes the knowledge transferred by CPA3.

"These tools which I developed, I will not provide them to our CPA. It is only for us."

"I made the tool my way. Our tables have a form of logic at the same time in their appearance, but also in the way in which they are built, which is very close to what we enjoy doing with our own clients. I apply the logic of our know-how to that."

Finally, it should be noted that neither CPA1 nor CPA2 transfer knowledge directly. It is via the knowledge transferred by CPA3 that the process of transformation of external knowledge of CPA3 and CPA2 is engaged and circumscribed with $\mathrm{H} 3 \mathrm{C}$. 
"In the long term, there will be a tool which mixes different management tools, those that are not tallied on a countable level, and those that are less normalized tools but that would be suitable."

The relationship between the entrepreneur and CPA3 is the fertile ground of the exploitation stage in the absorption process between the entrepreneur and CPA2. Finally, the absorption process is articulated around the construction of management tools by the entrepreneur. Through her complementary relationships with her various CPAs, the entrepreneur builds a comprehensive view of her company. The entrepreneur doesn't consider it as a series of projects any longer, but as an entity with a long term objective to recruit people and to project a revenue.

"We preserved a line for the bonuses of our collaborators. Then we started to project us on what we want as a result. The problem was: how much will we pay for corporate income tax?"

Finally, we show that MI generation in microentreprise is articulated around the relationship between the entrepreneur and the external CPA, but also around adapted and customized management tools which allow the transformation and exploitation of external knowledge, so the recombination of the latter, and thus the generation of managerial innovation. Thus, we highlight the instrumental relationship between the entrepreneur and the external CPA since management tools are essential in the absorption process, from a dynamic point of view. The entrepreneur builds her own management tools from those proposed by her CPA, adapting them to her needs. The explicit knowledge transferred by the CPA is re-contextualized by the entrepreneur in her own words, according to the organizational specificities. Knowledge is internalized by the entrepreneur through relational and instrumental drivers. Moreover, management tools are adapted by the entrepreneur in a mix of internal entrepreneur's and external CPA's knowledge. Therefore, the relationship between the entrepreneur and the CPA is a lever of management innovation in microentreprise. More particularly, this lever is not only relational but also instrumental. Combining internal and external knowledge, instrumental dynamics are complementary to the relationship between microentreprise change actors, who are the entrepreneur and the CPA.

This research conducted around a microenterprise echoes studies carried on SMEs, giving more attention on the realized absorptive capacity, that is on the exploitation and 
transformation stages rather than on potential capacity, namely the acquisition and assimilation steps, as Liao et al. (2003) recommended it. We show that management innovation in microentreprise is generated through the relationship between the entrepreneur and the CPA when these interrelations are instrumented, through customized management tools. This result completes what Volberda and his colleagues pointed out (2014): they stressed the personality of change actors in this relationship (2014). In this study, we first highlight the instrumental dimension of the relationship. On that point, we join Mol and Birkinshaw (2014) who suggested that "material agency and creativity (Amabile, 1997) will play a large role in management innovating" (Mol and Birkinshaw, 2014, p.1288). More precisely, considering material and instrumental relationship in knowledge combination for management innovating is consistent with socio-material view of human action (Suchman, 1987; Hutchins, 1995; Rabardel, 1995). And particularly, a structurationnist approach to technology (Barley, 1986; Orlikowski, 1992) shows how technology and thus management tools are an intimate support for action.

Lastly, this research illustrates the social dimension of knowledge and of innovation as combination of knowledge, as Gebauer et al. (2012) showed it in their study of strategic innovation in an absorptive capacity lens. As strategic innovation in SME (Gebauer et al., 2012), management innovation relies on combinative capabilities, which consist in systematizing, socializing and coordinating knowledge (Zollo and Winter, 2002).

\subsection{The key drivers of the MI generation in microentreprise: from the particular relationship between the entrepreneur and the CPA, to the competencies of the CPA as a microentreprise change actor}

In this research about management innovating in microentreprise, we point the key drivers of the relationship between the external change actor and the internal change actor, which may favor the generation of MI that is the realized ACAP. The cross-analysis of the three relationships between the $\mathrm{H} 3 \mathrm{C}$ entrepreneur and the three CPAs allows us to highlight two major key points of the relational factors between the entrepreneur and the CPA that may lead to an absorption process.

The first driver is the clear and stable relationship between the entrepreneur and the CPA. So that the entrepreneur internalizes the external CPA's knowledge, it is necessary that the entrepreneur and the CPA cooperate. Then a relationship can begin. 
"When I asked CPA2 who were his direct collaborators, he told us that it was a senior and that they were stable people."

But the entrepreneur must also find a coherence between the CPA's operating cognitive process and her operating cognitive process. On this point, we can note that the pedagogy of the CPAs, their transparency and their stability are essential to build a trusting and close relationship between an entrepreneur and an external knowledge partner such as a CPA.

\section{"I think that CPAI missed the target with us. He didn't understand who we were. He reproduced with us the general framework he used with many people.”}

"CPA2 was very good in business coaching? But once the structure was launched, I felt alone"

In other words, this research first highlights the dimensions of the relationship between the change actors, rather than the role of the change actors itself. The clearness, the stability and the closeness of the relationship between the entrepreneur and the CPA are essential to found the generation of management innovation. On that point, we join Mol and Birkinshaw (2014) when they point out that "management innovating is highly iterative and informal" (p. 1306). Secondly, three elements are essential to the absorptive process, and thus to the generation of a management innovation in microentreprises: the flexibility, accessibility, experience of the CPA as an external partner. In the study, we show that absorption process occurs when the knowledge absorption is fully completed, that is when external knowledge is completed into transformation and exploitation, and not simply acquisition and assimilation. For the entrepreneur, it means that knowledge is exploited in concrete actions. For instance, the development of adapted and evolutionary tools which thus combine managerial, external and internal knowledge through the relationship between the entrepreneur and the CPA generates management innovation.

More largely, a trusting climate is crucial to begin a relationship between an entrepreneur and a CPA. In this research, we highlight the cognitive and emotional dimensions of the relationship, regarding this one as the process of transformation of explicit knowledge transmitted by the CPA into tacit knowledge internalized by the entrepreneur. As Erden, Von Krogh and Nonaka (2008) underline it, "Coils, care, trust and commitment are crucial to profit high quality group tacit knowledge” (p. 15). However, if affection, care, confidence and commitment are requirements for the starting of this process of internalization of knowledge, 
they are not the sufficient conditions. We highlight the importance of the clearness and the stability of the commitment of the CPA, but also his accessible and flexible dimension. Doing so, this research echoes that of Flatter and her colleagues who proposed "an analysis of the connection between internal innovation management design - with an emphasis on knowledge transfer as a major dimension of ACAP - and the collaboration with strategic partners as external knowledge sources" (Flatten et al., 2011, p.137). Thus, the social competencies of the entrepreneur and the CPA are essential to generate management innovation, which relies on combinative capabilities (Zollo and Winter, 2002).

\section{Conclusion}

This research contributes to literature on management innovation, and more particularly on management innovation generation (Volberda et al., 2014) in microentreprises where the knowledge basis is less important than in bigger firms. Whereas Mol and Birkinshaw (2009, 2014) showed that relationships between external and internal partners could lead to the generation of management innovation, and participate in what they call "management innovating" (Mol and Birkinshaw, 2014), we highlight in this study how the relationship between change actors may be a lever of management innovation at a micro level.

We focus on the entrepreneur-CPA relationship to study how the relationship between the CPA as an external change actor and the entrepreneur as an internal change actor generates management innovation in microentreprise. More particularly, to grasp the micro foundations of management innovation generation, we analyze how the external CPA's knowledge can be internalized by the entrepreneur, through the acquisition, assimilation, transformation and exploitation of knowledge, that is absorptive capacity process (Cohen and Levinthal, 1990; Lane et al., 2006; Gebauer et al., 2012; Marabelli and Newell, 2014).

First, we show that management innovation in microentreprise is generated by an instrumental relationship between the change actors who are the entrepreneur and the CPA. Adapted and customized management tools play an important part, at least as important as the personalities and specificities of change actors (Volberda et al., 2014). Second, the study of the three relationships between an entrepreneur and her three CPAs helps us to highlight the key drivers of the relationship between internal and external change actors in microentreprises: the clearness and the stability of the relationship between the entrepreneur and the CPA, but also its accessible and flexible dimension. Doing so, we argue that, in the generation of 
management innovation, it is the nature of the relationship inside and outside the organization which matters more than actors as individuals.

Finally, this research contributes to literature on management innovation process (Volberda et al. 2014). We point out the importance of combinative capabilities (Zollo and Winter, 2002) for management innovation generation in microentreprise, considering both external and internal actors who have to be able to combine external and internal knowledge through socialization process. Following Mol and Birkinshaw (2014) who claim for management innovation as a kind of open innovation (Chesbrough, 2003), we propose to consider the entrepreneur and the CPA as open innovators who mobilize both external and internal sources of knowledge. And becoming an open innovator requires social skills that can be improved, both for the entrepreneur and for the CPA of microentreprises.

\section{References}

Amabile, T. M. (1997). Motivating creativity in organizations: On doing what you love and loving what you do. California Management Review, 40, 39-58.

Avenier, M.J. and C. Schmitt (2005), La communication des savoirs actionnables à diverses communautés de praticiens : chaînon souvent manquant dans la recherche. XIVème Conférence Internationale de l'AIMS, Angers.

Barley, S.R., (1986), Technology as an Occasion for Structuring: Observations on CT Scanners and the Social Order of Radiology Departments, Administrative Science Quarterly, 31, 78-108.

Beldi, A., and W. Cheffi (2005), La comptabilité de gestion : outil d'information ou dispositif de connaissance ? La perception des managers, 26ème Congrès de l'AFC, Lille, mai.

Bescos, P.L., and C. Mendoza (1998), Les besoins d'information des managers sont-ils satisfaits ?, Revue Française de Gestion, novembre-décembre, 117-128.

Birkinshaw, J., Hamel, G., and M.J., Mol, (2008), Management innovation. Academy of Management Review, 33: 4, 825-845.

Boland, J. R. and R.V Tenkasi (1995), Perspective making and perspective taking in communities of knowing. Organization Science, 6:4, 350-372.

Brannen, M.Y. (2004), When mickey loses face: recontextualisation, semantic fit, and the semiotics of foreignness. Academy of Management Review, 29:4, 593-616.

Chesbrough, H. (2003). Open innovation: The new imperative for creating and profiting from technology. Boston, MA: Harvard Business School Press.

Cohen, W., and D., Levinthal, (1990), Absorptive capacity: A new perspective on learning and innovation. Administrative Science Quarterly, 35: 128152. 
Damanpour, F., (1987), The adoption of technological, administrative, and ancillary innovations: Impact of organizational factors. Journal of Management, 13, 675-688.

Damanpour, F., (1991), Organizational innovation: a meta-analysis of effects of determinants and moderators. Academy of Management Journal, 5, 555-590.

Damanpour, F., and W.M., Evan, (1984), Organizational innovation and performance: the Problem of "organizational lag”, Administrative Science Quarterly, vol. 29, 392-409.

Damanpour, F., Szabat, K.A., and W.M., Evan, (1989), The relationship between types of innovation and organizational performance, Journal of Management Studies, vol. 26, $\mathrm{n}^{\circ} 6$, 1989, p. 587-601.

Davenport, T.H., and L. Prusak (1998), Working knowledge: how organizations manage what they know. Boston, Harvard Business School Press.

Dyer, J. H., and H. Singh (1998), The relational view: Cooperative strategy and sources of interorganizational competitive advantage. Academy of Management Review, 23: 660-679.

Erden, Z., G. Von Krogh G and I. Nonaka (2008), The Quality of Group Tacit Knowledge, Strategic Information Systems, 17, 4-18.

Fey, C., and J., Birkinshaw, (2005), External sources of knowledge, governance mode and R\&D performance. Journal of Management, 31, 597-621.

Freel, M. S., (2005). Patterns of innovation and skills in small firms. Technovation, 25(2), 123-134.

Freel, M.S., (1999), Where are the skills gaps in innovative small firms?, International Journal of Entrepreneurial Behaviour \& Research, Vol. 5 No. 3, 144-54.

Gavigan, J. P., M. Ottitsch and S. Mahroum (1999), Knowledge and learning: towards a learning Europe, European commission, Institute for Prospective Technological Studies, 91.

Gebauer, H., Worch, H., Truffer, B. (2012). Absorptive capacity, learning processes and combinative capabilities as determinants of strategic innovation. European Management Journal, 30(1), 57-73.

Gray, C., (2006), Absorptive capacity, knowledge management and innovation in entrepreneurial small firms. International Journal of Entrepreneurial Behaviour and Research, 12, 345-360.

Hamel, G., (2006), The why, what and how of management innovation, Harvard Business Review, 74-84.

Hendriks, P. (1999), Why share knowledge? The influence of ICT on the motivation for knowledge sharing. Knowledge and Process Management, 6:2, 91-100.

Hull, R. (1998), The conduct of expert labour: knowledge management practices, in R\&D, Centre for research on innovation and competition, Manchester 
Hutchins, E. (1995), Cognition in the Wild, MIT Press.

Imbert, G., and V. Chauvet (2012), De la capacité d'absorption à la capacité d'insémination. Revue française de gestion, (2), 111-127.

Jansen, J. J., Van Den Bosch, F. A., and H.W., Volberda, (2006), Exploratory innovation, exploitative innovation, and performance: Effects of organizational antecedents and environmental moderators, Management science, 52 : 11, 1661-1674.

Katila, R., and G,. Ahuja, (2002), Something old, something new: A longitudinal study of search behavior and new product introduction. Academy of Management Journal, 45, 1183-1194.

Lane, P. J., and M. Lubatkin (1998), Relative absorptive capacity and interorganizational learning. Strategic Management Journal, 19: 461-477.

Lane, P. J., Koka, B. R., and S., Pathak, (2006), The reification of absorptive capacity: a critical review and rejuvenation of the construct. Academy of management review, 31(4), 833-863.

Laursen, K., and A., Salter, (2006), Open for innovation: The role of openness in explaining innovative performance among UK manufacturing firms. Strategic Management Journal, 27, 131-150.

Liao, J., Welsh, H. and M., Stoica, (2003), Organizational absorptive capacity and firm responsiveness: an empirical investigation of growth-oriented firm, Entrepreneurship Theory and Practice, Autumn, 63-85.

Marabelli, M., and Newell, S. (2014). Knowing, power and materiality: A critical review and reconceptualization of absorptive capacity. International Journal of Management Review, 16(4), 479-499.

Marti, C. (2005), L'apport des méthodes narratives à la gestion des connaissances : le partage et la réutilisation entre artisans. Thèse de doctorat, Sciences de Gestion. Montpellier, Université Montpellier 2: 398 p.

Miles, M. B., and A.M., Huberman, (2003), Analyse des données qualitatives, De Boeck Supérieur.

Mintzberg, H. (2006), Structure et dynamique des organisations, Englewood Cliffs, NJ : Prentice Hall.

Mol M. J., and Birkinshaw J. (2014), The role of external involvement in the creation of management innovations, Organization Studies, 35(9), p. 1287-1312.

Mol, M. J. and J. Birkinshaw, (2009), The sources of management innovation: When firms introduce new management practices. Journal of Business Research, 62: 12, 1269-1280.

Nahapiet, J., and S. Ghoshal, (1998). Social capital, intellectual capital, and the organizational advantage. Academy of Management Review, 23(2), 242-266.

Nonaka, I. (1994), A Dynamic Theory of Organizational Knowledge Creation, Organization Science, 5: 1, 14-37. 
Nonaka, I. and H. Takeuchi (1997), La connaissance créatrice - La dynamique de l'entreprise apprenante. De Boeck.

Nonaka, I., (1991), The knowledge creating company. Harvard Business Review, 69, (NovDec), 96-104

Orlikowski, W.J., (1992), The Duality of Technology: Rethinking the Concept of Technology in Organizations, Organization Science, 3: 3, 398-427.

Rabardel, P. (1995), Les hommes et les technologies, approches cognitive des instruments contemporains, Armand Colin.

Rosenkopf, L., and A., Nerkar, (2001), Beyond local search: Boundary-spanning, exploration, and impact in the opticaldisk industry. Strategic Management Journal, 22: 287-306.

Suchman, L. (1987), Plans and situated actions. The problem of human machine communication, Cambridge University Press.

Thompson, P., C. Warhurst and G. Callaghan (2001), Ignorant theory and knowledgeable workers: interrogating the connections between knowledge skills and services, Journal of Management Studies, 38: 7, 923-942.

Vallerand, J., S. Berthelot and J. Morrill (2008), Positionnement de la PME manufacturière canadienne face aux outils de gestion enseignés dans les programmes de formation universitaire en administration, 9ème CIFEPME, Louvain la Neuve.

Van de Ven, A. H. (1986). Central problems in the management of innovation. Management science, 32(5), 590-607.

Volberda H.W., Van Den Bosch F., Mihalache, O. R. (2014), Advancing Management Innovation: Synthesizing Processes, Levels of Analysis, and Change Agents, Organization Studies, 35(9), p. 1245-1264.

Yin, R. (2003), Case Study Research. Design and Methods. Third Edition, Sage Publications.

Zahra, S. A., and G., George, (2002), Absorptive capacity: A review, reconceptualization, and extension. Academy of Management Review, 27, 185-203.

Zollo, M., and S. G., Winter, (2002). Deliberate learning and the evolution of dynamic capabilities. Organization Science, 13(3), 339-351. 
Table 1: Entrepreneur-CPA's relationship, absorptive capacity process and realized absorptive capacity

\begin{tabular}{|c|c|c|c|}
\hline & $\begin{array}{c}\text { Absorptive } \\
\text { Process with } \\
\text { CPA1 }\end{array}$ & $\begin{array}{c}\text { Absorptive } \\
\text { Process with } \\
\text { CPA2 }\end{array}$ & $\begin{array}{c}\text { Absorptive } \\
\text { Process with } \\
\text { CPA3 }\end{array}$ \\
\hline Acquisition & $\mathrm{X}$ & $\mathrm{X}$ & $\mathrm{X}$ \\
\hline Assimilation & & $\mathrm{X}$ & $\mathrm{X}$ \\
\hline Transformation & & $\mathrm{X}$ & $\mathrm{X}$ \\
\hline Exploitation & & $\mathrm{X}$ & $\mathrm{YES}$ \\
\hline Realized ACAP & $\mathrm{NO}$ & IN PROGRESS & \\
\hline
\end{tabular}

Figure 1: Realized ACAP in Relationship 3 (Entrepreneur-CPA3)

\section{ACAP PROCESS}
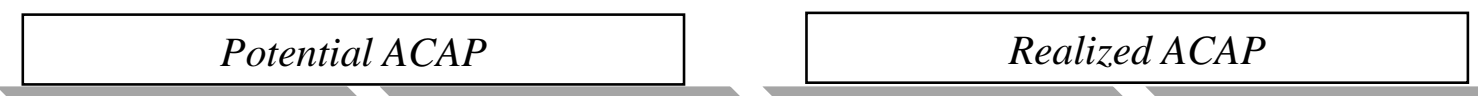

Acquisition

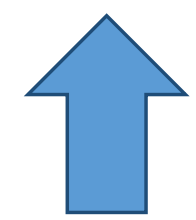

Knowledge clarification
Assimilation

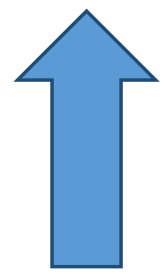

Management tool proposition by CPA
Transformation

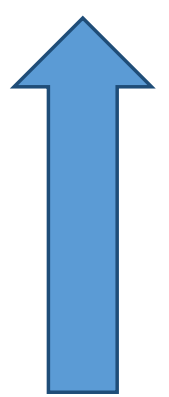

Simplification and translation
Exploitation

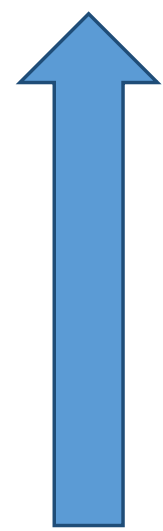

Instrumental adaptation and tool customization 